INFO ARTIKEL

Riwayat Artikel:

Diterima : 23 Juli 2020

Disetujui : 15 Agustus 2020

\title{
GEOGRAFI
}

\section{PERSEPSI MASYARAKAT TERHADAP PROGRAM REVITALISASI SUNGAI SEKANAK DI KOTA PALEMBANG}

\author{
Hesti Wulandari $^{1}$, Maharani Oktavia ${ }^{2}$, Eni Heldayani ${ }^{3}$ \\ ${ }^{1-3}$ Program Studi Pendidikan Geografi, FKIP, Universitas PGRI Palembang \\ $(\square)$ hestiwulandari980@gmail.com
}

\begin{abstract}
ABSTRAK
Tujuan pada penelitian ini untuk mengetahui bagaimana persepsi masyarakat terhadap program revitasi sungai sekanak di kota palembang. Metode yang digunakan dalam penelitian ini adalah metode suvei dengan menggunakan teknik pengumpulan data angket. Melibatkan informan kunci dengan teknik purposive sampling dan teknik analisis data yang digunakan yaitu skala likert. Hasil penelitian ini menunjukan bahwa persepsi masyarakat terhadap program revitalisasi sungai sekanak di Kota Palembang meliputi kondisi fisik, kondisi sosial, dan kondisi ekonomi baik dengan rata-rata masyarakat yang menyatakan setuju terdapat $43 \%$ rsponden, sedangkan menyatakan ragu-ragu 31\% responden, dan yang tidak setuju 9.33\%. Dalam hal ini peneliti menarik kesimpulan bahwa persepsi masyarakat terhadap program revitalisasi sungai sekanak yaitu baik.
\end{abstract}

Kata Kunci: Permukiman, Sungai Sekanak, Revitalisasi

\begin{abstract}
The purpose of this study was to determine how the community's perception of the Sekanak river revitalization program in the city of Palembang. The method used in this research is a survey method using a questionnaire data collection technique. Involving key informants with purposive sampling technique and data analysis technique used is the Likert scale. The results of this study indicate that the public perception of the Sekanak river revitalization program in Palembang City includes physical conditions, social conditions, and good economic conditions with an average community who agrees that there are $43 \%$ respondents, while $31 \%$ of respondents expressed doubt, and those who disagree $9.33 \%$. In this case the researcher draws the conclusion that the public perception of the Sekanak river revitalization program is good.
\end{abstract}

Keywords: Settlements, Sekanak River, Revitalization

\section{PENDAHULUAN}

Perumahan dan permukiman adalah satu kesatuan sistem yang terdiri atas pembinaan, penyelengaraan perumahan, dan penyelenggaraan kawasan, perumahan merupakan kelompok rumah yang berfungsi sebagai lingkungan tempat tinggal yang dilengkapi prasarana dan sarana lingkungan sedangkan, permukiman merupakan bagian dari lingkungan yang berupa kawasan perkotaan dan pedesaan yang berfungsi sebagai lingkungan tempat tinggal atau lingkungan dalam perumahan dan permukiman pencegahan dan peningkatan kualitas terhadap perumahan dan permukiman kumuh sangat di perhatikan (Hikon, 2019:108). Kebutuhan perumahan bagi masyarakat yang berada diperkotaan yang berpenghasilan rendah bisa memunculkan suatu daerah permukiman kumuh terutama di kota-kota besar dan metropolitan maka dari itu terwujudnya kesejahteraan rakyat dapat ditandai dengan meningkatnya kualitas kehidupan yang layak dan 
berkecukupan agar dapar mengurangi suatu permukiman kumuh (Marwati, 2008:67).

Menurut Hadi Sabari Yunus (1987, di kutip dari Wesnawa, 2015:2) Permukiman dapat diartikan sebagai bentuk baik buatan manusia ataupun alami dengan segala kelengkapannya yang digunakan manusia sebagai individu maupun kelompok untuk bertempat tinggal baik sementara maupun menetap dalam menyelengarakan kehidupannya. Dengan demikian upaya pembenahan di bidang perumahan dan permukiman sebagai salah satu sektor prioritas dalam pembangunan nasional Indonesia guna untuk meningkatkan mutu kehidupan masyarakat dan terwujudnya perumahan dan permukiman yang layak huni dan bebas kumuh (Direktorat Pengembangan Kawasan Pemukiman. (2016).

Tingginya jumlah penduduk dipusat kota mengharuskan terpenuhinya kebutuhan akan permukiman yang layak huni, khususnya untuk menampung kaum urbanis yang pekerjaannya terkonsentrasi, pada sektor perdagangan dan jasa dikawasan komersial yang ada dipusat kota (Rahmawati, 2012:1). Ketersediaan sarana dan prasarana yang lengkap dipusat Kota ini menimbulkan daya tarik bagi masyarakat untuk bermukim di kawasan tersebut. Mereka membutuhkan tempat hunian lebih banyak berada disekitar kawasan komersial kota, hal ini dimungkinkan juga karena mereka mendekati pusat perdagangan untuk membuka usaha dengan memanfaatkan keramaian dan padatnya pengunjung yang berdatangan ke pusat-pusat perbelanjaan di kota sehingga munculnya suatu permukiman kumuh di perkotaan, dengan munculnya permukiman kumuh di perkotaan dapat menyebabkan suatu perkotaan menjadi tak indah untuk dilihat.

Peningkatan kualitas terhadap permukiman yang memiliki tipologi kumuh di Kota Palembang masih terkonsentrasi pada pembangunan fisik seperti perbaikan jalan, saluran, penyediaan air bersih serta perbaikan rumah. Namun aspek terhadap kondisi sosial, ekonomi terutama komitmen masyarakat dalam peranannya menjaga kualitas lingkungan permukiman belum terlihat. Selain itu belum ada peran stakeholder (pemangku kepentingan) yang melibatkan akademisi, swasta dan pemerintah serta masyarakat lainnya untuk menilai dalam menentukan prioritas peningkatan kualitas permukiman di Kota Palembang. Permukiman kumuh di Kota Palembang tersebar di 59 spot (titik), dengan luas sekitar $2.473 \mathrm{Ha}$, salah satunya daerah yang memiliki tipologi kumuh berat yaitu daerah 29 Ilir dengan luas lahan 16,73 ha, jumlah penduduk 8.928 jiwa dan merupakan bagian dari wilayah administrasi Kecamatan Ilir Barat II serta berdekatan ditepian sungai musi, pusat pemerintahan, ekonomi dan pariwisata di Kota Palembang (Mutaqin, Persada, \& Suroso, 2012:66).

Permukiman kumuh didalam kota harus dikurangi atau dicegah, dalam rangka meminimalisir munculnya kawasan kumuh, maka dilakukan upaya-upaya yang mempunyai wawasan luas yang menyangkut berbagai aspek yang mampu menghambat timbulnya kawasan kumuh tersebut. Salah satu pembangunan alternatif yang harus dilakukan di Indonesia dalam rangka mengurangi permukiman kumuh adalah pengembangan kawasan kumuh menjadi sektor pariwisata untuk mengurangi permukiman kumuh diperkotaan (Hikon, 2019:108). Menurut (Slameto, 2010) persepsi adalah proses yang menyangkut masuknya suatu pesan dan informasi di dalam otak manusia. Informasi tersebut muncul dalam bentuk yang stimulasi yang diterima individu melalui indera sedangkan masyarakat adalah kumpulan orang yang sudah terbentuk sejak sudah lama dan berinteraksi sesama kumpulannya dan masyarakat juga telah memiliki sosial tersendiri, memiliki kepercayaan masing-masing dan prilaku yang dimilik berbeda. Berdasarkan uraian diatas bahwa persepsi masyarakat merupakan kumpulan orang yang memiliki tanggapan atau pandangan seseorang terhadap lingkungan yang ada disekitarnya sehingga individu sadar akan segala sesuatu dalam lingkunganya melalui indera-indera yang dimilikinya dan memberikan suatu penilaian.

Kota Palembang telah mempunyai kerangka kebijakan sektor perumahan yang jelas terlihat dari adanya visi dan misi pembangunan perumahan. Visi pembangunan perumahan yang diusung kota ini berupa house off all ( rumah rumah layak huni dan dan sehat untuk semua 
warga kota). Misi untuk mencapai visi tersebut meliputi: membebaskan lahan untuk memenuhi kebutuhan rumah bagi MBR, memindahkan masyarakat pinggiran sungai musi ke tempat yang lebih layak, memenuhi kebutuhan rumah untuk masyarakat Kota Palembang dan membuat rumah sehat dan terjangkau oleh warga. Menyadari banyaknya kawasan kumuh yang yang ada di sekitar kota ini maka pemerintah kota membuat program revitalisasi kawasan kumuh sebagai bagian dari program strategis penataan kota dari program pemerintah ini sudah hampir berjalan dengan lancar program yang sudah terlaksana seperti bedah rumah, sanitasi, retorasi sungai, penanggulangan limbah dan program ruang terbuka hijau.

Program dikembangkan dengan menggunakan pendekatan konsep penataan secara kawasan. Program tersebut meliputi penataan terhadap lingkungan dan manusia, yang diantara keduanya harus saling terpadu. Upaya untuk memadukanya di tempuh pemda dengan cara mengupayakan semua program yang terkait dua hal tersebut masuk dalam satu lokasi pilot project revitalisasi kawasan kumuh (Muta'ali \& Nugroho, 2016:118). Revitalisasi merupakan merupakan upaya untuk mengembalikan vitalitas suatu kawasan atau bagian kota yang dulunya pernah vital, namun mengalami penurunan vitalitas baik secara fisik, ekonomi, sosial dan budaya. Dalam proses pendekatannya, revitalisasi harus mampu mengenali dan memanfaatkan potensi lingkungan fisik maupun non-fisik yaitu sejarah, makna, keunikan lokasi, dan citra tempat. Maka, revitalisasi tidak hanya berorientasi pada keindahan fisik tetapi juga harus mampu meningkatkan stabilitas lingkungan, pertumbuhan perekonomian masyarakat, pelestarian, dan pengenalan budaya suatu kawasan (Arbani \& Idajati, 2017).

Sungai sekanak yang merupakan anak sungai musi, mengalir membelah kawasan sekanak, keberadaan sungai sekanak ini tidak bisa lepaskan dari perkembangan morfologi kota palembanga karena sungai sekanak ini juga termasuk tempat bersejarah di Kota Palembang, sungai sekanak memiliki cukup penting bagi perkembangan morfologi di Kota Palembang.
Sungai sekanak yang berada di pinggir sungai musi ini dan berada di tengah kota dulunya sangat kumuh karena berada disekitaran rumah-rumah penduduk dan berada disekitar pasar yang tidak peduli terhadap sungai disekitar mereka, sehingga sungai sekanak hanya dijadikan tempat pembungan sampah dan kondisi sungai sangat terlihat kumuh dan banyak sampah-sampah, apabila musim hujan sungai sekanak sering banjir karena banyaknya sampah.

Pemerintah sangat berperan aktif dalam membangun sebuah kota agar dapat terlihat rapi dan tertata seperti di Kota Palembang disalah satu daerah yang terlihat kumuh kini dibangun menjadi salah satu tempat yang bisa dijadikan kawasan wisata. Setelah pemerintah melihat kedaan disekitar sungai sekanak pemerintah langsung melukukan suatu program yaitu program revitalisasi sungai, revitalisasi mulai dilakukan pada tahun 2018 revitalisasi ini dilakukan untuk meningkatkan kepedulian masyarakat terhadap sungai sehingga sungai tidak terlihat kumuh dan juga sungai sekanak bisa juga dimanfaat masyarakat untuk berwisata. Dari permasalahan diatas penelitian tertarik untuk mengetahui bagaimana Persepsi Masyarakat Terhadap Program Revitalisasi Sungai Sekanak Di Kota Palembang.

\section{METODE PENELITIAN}

Metode penelitian ini menggunakan metode penelitian survei adalah suatu metode penelitian yang bertujuan untuk mengumpulkan sejumlah besar variabel mengenai individu melalui angket.

Dalam penelitian ini populasi yang diperlukan adalah masyarakat yang bertempat tinggal di RT 2. Untuk pengambilan sampel dilapangan peneliti menggunakan teknik quantum sampling yang menentukan sampel dari populasi yang mempunyai ciri-ciri tertentu sampai jumlah ditetapkan karena keterbatasan waktu untuk melakukan penelitian dilapangan karena situasional yang ada dilapangan, untuk penelitian ini peneliti menetapkan jumlan sampel 30 orang dan untuk menentukan responden peneliti menggunakan teknik accidental sampling. Sedangkan Accidental sampling merupakan siapa saja yang ditemui dilapangan pada saat penelitian atau yang ditemui secara kebetulan dilingkungan 
sungai sekanak dan responden pada penelitian ini ada 30 responden yang sudah ditetapkan.

Maka Metode yang digunakan dalam penelitian ini adalah metode penelitian survei untuk mencapai tujuan penelitian. Dari penelitian ini di harapkan mampu untuk memberikan gambaran bagaimana tanggapan masyarakat terhadap program revitalisasi sungai sekanak di Kota Palembang. Menurut Sugiyono (2016:308), teknik pengumpulan data merupakan langkah yang paling utama dalam penelitian, karena tujuan utama dari penelitian adalah untuk mendapatkan data. Pada penelitian ini sumber data yang digunakan yaitu ada dua sumber data primer dan sumber data sekunder. Untuk teknik pengumpulan data dalam penelitian ini menggunakan teknik angket.

Sugiyono (2016: 199) menyatakan bahwa teknik pengumpulan data yang dilakukan dengan cara memberi seperangkat pertanyaan atau pertanyaan tertulis kepada responden untuk dijawab. Pada penelitian ini angket di tujukan kepada masyarakat setempat di lokasi penelitian data yang akan di ambil oleh peneliti yaitu sikap dan tanggapan masyarakat tentang persepsi masyarakat terhadap program revitalisasi sungai sekanak di Kota Palembang. Berikut lokasi penelitian pada gambar. 1 .

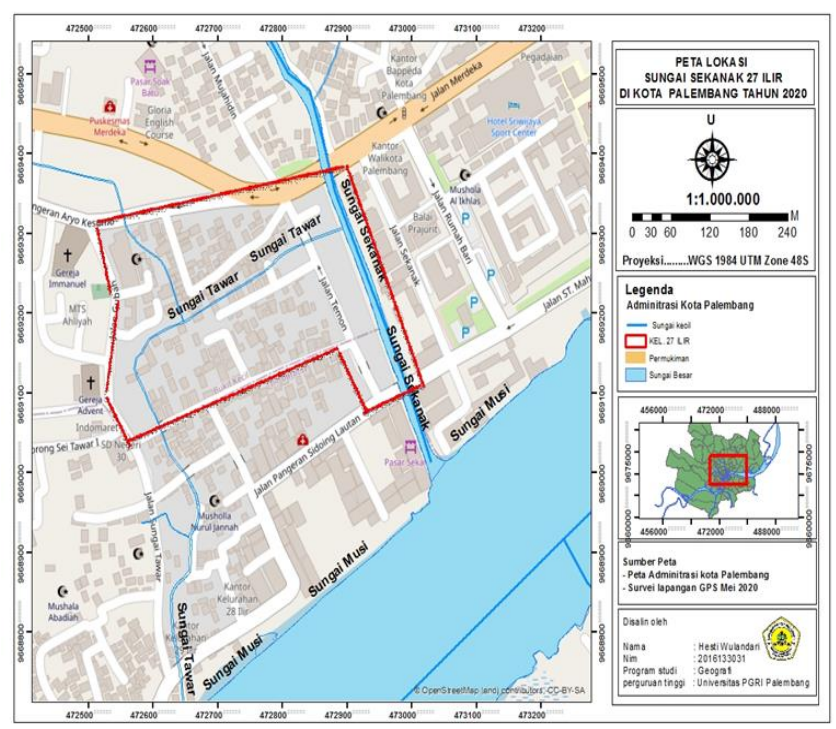

Gambar. 1. Peta Lokasi

\section{HASIL DAN PEMBAHASAN}

Revitalisasi sungai menjadi salah satu bentuk fasilitas umum yang bermotif untuk suatu perubahan seperti perubahan fisik, sosial dan ekonomi. Salah satunya di kota Palembang yaitu revitalisasi sungai sekanak dengan adanya revitalisasi sungai sekanak ini dapat banyak membuat perubahan seperti perubahan kondisi fisik, kondisi sosial dan kondisi ekonomi.

Penelitian ini berfokus pada persepsi masyarakat yang telah diukur dengan indikator yang telah ditentukan, ada 3 indikator dalam penelitian ini yaitu fisik, sosial dan ekonomi. Hasil dari penelitian yang mengenai persepsi masayarakat terhadap program revitalisasi sungai sekanak di kota Palembang adalah sebagai berikut.

\section{Persepsi Masyarakat Tentang Kondisi Fisik Sungai Sekanak Setelah Program Revitalisasi Sungai}

Fisik adalah memperhatikan konteks lingkungan yang akan direvitalisasi yang dilandasi perencanaan. Dalam penelitian ini yang dilihat perubahan fisik seperti kondisi sungai setelah revitalisasi sudah tidak keruh, kondisi sungai setelah revitalisasi sudah tidak ada sampah lagi, kondisi sungai setelah revitalisasi sudah tidak kumuh lagi, dan masyarakat menfaatkan air sungai untuk keperluan sehari-hari setelah revitalisasi. Pada hasil penelitian untuk dibagian indikator pertama tentang sungai sekanak tidak keruh lagi, dari analisi diatas dapat dilahat bahwa sebagian responden menyatakan $46.6 \%$ ragu-ragu bahwa air sungai tidak keruh lagi. Karena air sungai sekanak dapat berubah-ubah tidak setiap harinya tidak keruh, air sungai tidak keruh saat dimusim hujan karena air mengalir apabila musim kemarau air sungai sekanak kembali lagi keruh. Untuk sungai tidak ada sampah lagi hasil analisinya diatas dapat dilihat bahwa sebagian responden menyatakan $46.7 \%$ karena setelah direvitalisasi air sungai tidak terlihat lagi sampah karena masyarakat tidak pernah lagi membuang sampah di lingkungan sungai dan juga ada petugas yang membersihkan sampah di lingkungan sungai sehingga sungai tidak ada sampah lagi.

Untuk sungai tidak kumuh lagi hasil analisinya diatas dapat dilihat sebagian masyarakat menyatakan $76.7 \%$ setuju bahwa sungai tidak kumuh lagi dengan adanya revitalisasi ini lingkungan disekitar sungai tidak 
kumuh lagi karena sudah beberapa bangunan warna-warni di sekitaran sungai sekanak sehingga membuat ligkungan sungai tidak ter;ihat kumuh lagi dan dubagian pemanfaatan air sungai hasil analisinya diatas dapat dilihat bahwa $40 \%$ responden menyatakan ragu-ragu karena masyarkat disekitaran sungai tidak sepenuhnya memanfaatkan air sungai untuk kebutuhan seharihari. Masyarakat menfaatkan air sungai misalnya hanya untuk mencuci kendaraan dan juga saat musim kemarau masyarakat sering menggunakan air sungai tetapi tidak sepenuhnya karena masyarakat untuk sehari-hari lebih menggunakan air PDAM.

\section{Persepsi Masyaraka Terhadap Kondisi Sosial Setelah Revitalisasi Sungai Sekanak}

Revitalisasi sebuah kawasan akan terukur bila mampu menciptakan lingkungan yang menarik sepertihalnya revitalisasi sungai tersebut harus berdampak posistif serta dapat meningkatkan dinamika dan kehidupan sosial masyarakat setempat. Dalam penelitian ini dilihat dari perubahan sosial seperti setelah revitalisasi sungai sikap peduli lingkungan lebih peduli, masyarakat membuang sampah pada tempatnya, masyarakat setelah revitalisasi sehat setelah revitalisasi sungai, dan masyarakat bergotong royong dalam menjaga lingkungan disekitar sungai sekanak. Setelah peneliti memberikan angket ke responden peneliti dapat melihat angka yang lebih terlihat di perubahan sosial. Untuk indikator peduli lingkungan dari analisi diatas dapat lihat bahwa $60 \%$ responden menyatakan masyarakat lebih peduli lingkungan karena setelah sungai di revitalisasi banyak sekali perububahan dari sikap masyarakat yang dulunya tidak peduli dengan lingkungan disekitar sungai sekarang masyarakat lebih peduli terhadap lingkungan sekitar sungai sekanak dan masyarakat sangat antusias dengan adanya revitalisasi ini.

Untuk dibagian indikator masyarakat sudah membuang sampah pada tempatnya dari analisi diatas dapat dilihat bahwa $60 \%$ responden menyatakan setuju, karena setelah revitalisasi masyarakat dilarang membungan sampah disekitar sungai dan sekarang masyarak telah di siapkan tempat untuk mereka membuang sampah berbeda pada saat sebelum revitalisasi pada saat revitalisasi masyarkat masih membuang sampah disungai karena dulu belum ada tempat sampah yang memadai sehingga masyarakat dulu membuang sampah disungai.

Indikator kesehatan dari analisi diatas dapat dilihat $50 \%$ responden menyatakan setuju karena setelah revitalisasi ini lingkungan lebih bersih dan tertata sehingga menimbulkan hidup yang sehat dan masyarakat sering melakukan jogging atau berolahraga dipinggir sungai pada saat minggu pagi. Karena udara dilingkungan sungai terasa lebih nyaman untuk dijadikan tempat oleh masyarakat untuk mencari udara, berbeda pada saat sebelum revitalisasi masyarakat sering mencium bauk busuk dilingkungan sungai karena sungai dipenuhi sampah sehingga mengganggu aktivitas masyarakat. Pada bagian masyarakat sudah bergotong royong dalam menjaga lingkungan dari analisis diatas dapat dilihat bahawa $63.3 \%$ responde menyatakan setuju, masyarakat setelah revitalisasi sudah mulai bergotong royong dalam menjaga lingkungan sekitar sungai. Masyarakatpun sering melakukan gotong royong pada hari minggu dan gotong royong ini pun memangrutin dilakukan masyarakat dan juga gotong royong ini sudah diterapkan setelah revitalisasi sungai dan dari kelurahan pun rutin mengajak masyarakat untuk bergotong royong di lungkungan sungai sekanak agar sungai tetap terjaga dan bersih dari sampah.

\section{Persepsi Masyarkat Terhadap Kondisi Ekonomi Setelah Revitalisasi Sungai Sekanak}

Perbaikan fisik kawasan yang bersifat untuk merubah suatu tempat yang lebih menarik lagi revitalisasi yang diintruduksi dengan proses pemanfaat kawasan sungai harus mendukung proses rehabilitasi aktivitas ekonomi. Dalam penelitian ini dilihat dari perubahan ekonomi seperti dengan adanya revitalisasi sungai sekanak dampak ekonomi lebih meningkat dan adanya revitalisasi sungai daya tarik beli yang dirasakan meningkat.

Untuk di indikator bangkitan ekonomi dari hasil analisis diatas dapat dilihat bahwa $46.6 \%$ responden yang menyatakan ragu-ragu karena masyarakat disekitar sungai dilarang untuk berjualan. Pemerintah menghimbau masyarakat untuk tidak berjualan disekitar sungai agar 
lingkungan sungai tidak tecemari dengan sampah makanan-makanan. Sehingga setelah adanya revitalisasi sungai tidak memungkinkan adanya bangkitan masyarakat yang tinggal sekiran sungai sekanak. Sedangkan untuk daya tarik meningkat dari hasil analisis diatas dapat dilihat bahwa $60 \%$ responden menyatakan sangat tidak setuju karena sekitaran sungai tidak boleh berjualan sehingga tidak meningkatkan daya tarik beli meningkat. Hanya saja daya tarik masyarakt untuk datang ke sungai sekanak lebih meningkat masyarakat yang datang baik dari Palembang bisa juga dari luar Kota Palembang, masyarakat yang datang hanya melihat-lihat dan berfoto-foto di sungai sekanak.

Berdasarkan hasil penelitian diatas dapat di lihat dari 3 indikator tersebut salah satunya lingkungan fisik disekitar sungai sekanak dapat banyak perubahan dari kualaitas air, tempattempat yang lainya. Dibagian indikator ke dua yaitu kondisi sosial dengan adanya revitalisasi sungai sekanak ini kepedulian masyarakat terhadap lingkungan dan kekompakan lebih meningkat lagi, hal ini tentu perlahan akan mengubah pola pikir masyarakat sekitar sungai menjadi terarah dan menumbuhkan nilai-nilai sosial dari masyarakat berawal dari pola pikir yang sehat dan terarah. Dibagian ke tiga yaitu ada perekonomian, untuk perekonomian disekitar lingkungan sungai sekanak tidak mengalami peningkatan karena pemerintah menghimbau masyarakat untuk untuk tidak berjualan disekita sungai sekanak, akan lebih bagusnya pemerintah juga bisa memanfaatkan tempat tesrsebut untuk manfaat kan untuk masyarakat berjualan agar perekonomian mereka lebih meningkat lagi dengan adanya wisata sungai sekanak.

\section{KESIMPULAN}

Berdasarkan hasil penelitian dan pembahasan di atas maka dapat di simpulkan bahwa persepsi masyarakat terhadap program revitalisasi sungai sekanak di Kota Palembang meliputi kondisi fisik, kondisi sosial dan kondisi ekonomi adalah baik. Mengapa diakatan baik karena hasil angket rata-rata yang menyatakan setuju terdapat $43 \%$ responden karena ada perubahan di kondisi fisik, kondisi sosial dan di kondisi ekonomi sedangkan menyatakan ragu- ragu $31 \%$ responden dan yang tidak setuju $9.33 \%$, jadi dari persentase angket diatas dapat disimpulkan bahwa persepsi masyarakat terhadap program revitasli sungai sekanak yaitu baik.

\section{DAFTAR PUSTAKA}

Arbani, Inggar Rayi dan Idajati, Hertiari, (2017). Identifikasi Potensi dan Masalah dalam Revitalisasi Kawasan Sungai Kalimas di Surabaya Utara. JURNAL TEKNIK ITS Vol. 6, No. 2.

Direktorat Pengembangan Kawasan Pemukiman. 2016. Panduan Pendampingan Penyusunan Raperda tentang Pencegahan dan Peningkatan Kualitas Perumahan Kumuh dan Permukiman Kumuh. Jakarta: Direktorat Jenderal Cipta Karya Kementerian Pekerjaan Umum dan Perumahan Rakyat.

Hikon, W. M. (2019). Strategi pemberdayaan masyarakat dalam mengubah permukiman kumuh menjadi destinasi wisata. Jurnal Ilmu Sosial dan Ilmu Politik, 108.

Marwati, G. (2008). Peremajaan Permukiman Melalui Keswadayaan Masyarakat. Jurnal Permukiman , 66-78

Muta'ali, 1., \& nugroho, r. (2016). perkembangan program penanganan permukiman kumuh di indonesia dari masa ke masa. Yogyakarta: gadjah mada university press.

Mutaqin dkk. (2019). Prioritas Penentuan Peningkatan Kualitas Lingkungan Permukiman Kumuh yang Berkelanjutan J. Presipitasi, Vol .16 No 2: 22-32.

Rahmawati, Agustina dkk. (2012). Strategi Penanganan Permukiman Kumuh (Studi Kasus : Kawasan Kaligawe, Semarang). Journal Of Public Policy And Management Review. https://ejournal3.undip.ac.id/index.php/jpp mr/article/view/139/147.

Slameto. 2010. Belajar dan faktor-faktor yang Mempengaruhinya. Jakarta: PT. Rineka Cipta

Sugiyono. (2016). Metode Penelitian pendidikan . Bandung: Alfabeta. 